\title{
Chikungunya virus infections among travellers returning to Spain, 2008 to 2014
}

MD Fernandez-Garcia ${ }^{123}$, M Bangert ${ }^{1345}$, F de Ory ${ }^{1}$, A Potente ${ }^{1}$, L Hernandez ${ }^{1}$, F Lasala ${ }^{1}$, L Herrero ${ }^{1}$, F Molero ${ }^{1}$, A Negredo

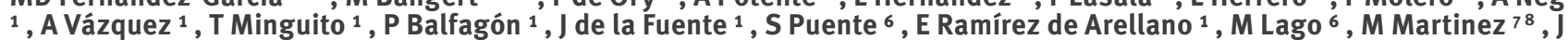
Gascón 7 , F Norman ${ }^{9}$, R Lopez-Velez ${ }^{9}$, E Sulleiro ${ }^{10}{ }^{11}$, D Pou ${ }^{11}$, N Serre ${ }^{11}$, RF Roblas ${ }^{12}$, A Tenorio ${ }^{1}$, L Franco ${ }^{1313}$, MP Sanchez$\operatorname{Seco}^{13}$

1. Centro Nacional de Microbiología, Instituto de Salud Carlos III, Madrid, Spain

2. Current affiliation: Institut Pasteur de Dakar, Dakar, Senegal

3. These authors contributed equally to this manuscript

4. Current affiliation: World Health Organization, Geneva, Switzerland

5. European Union Public Health Microbiology training programme (EUPHEM), European Centre for Disease Prevention and Control (ECDC), Stockholm, Sweden

6. Hospital Carlos III-La Paz, Madrid, Spain

7. ISGlobal, Barcelona Centre for International Health Research (CRESIB), Hospital Clínic-Universitat de Barcelona, Barcelona, Spain

8. Department of Clinical Microbiology, Hospital Clínic, Barcelona, Spain

9. Hospital Ramon y Cajal, Madrid, Spain

10. Department of Microbiology, Hospital Universitari Vall d'Hebron, Barcelona, Spain

11. Tropical Medicine and International Health Unit Drassanes-Vall d'Hebron, PROSICS Barcelona, Barcelona, Spain

12. Fundación Jimenez Diaz, Madrid, Spain

13. Current affiliation: Gorgas Memorial Institute, Panama City, Panama

Correspondence: Leticia Franco (francolet@gmail.com)

Citation style for this article:

Fernandez-Garcia MD, Bangert M, de Ory F, Potente A, Hernandez L, Lasala F, Herrero L, Molero F, Negredo A, Vázquez A, Minguito T, Balfagón P, de la Fuente J, Puente S, Ramírez de Arellano E, Lago M, Martinez M, Gascón J, Norman F, Lopez-Velez R, Sulleiro E, Pou D, Serre N, Roblas RF, Tenorio A, Franco L, Sanchez-Seco MP. Chikungunya virus infections among travellers returning to Spain, 2008 to 2014. Euro Surveill. 2016;21(36):pii=30336. DOI: http://dx.doi.org/10.2807/15607917.ES.2016.21.36.30336

Article submitted on 26 August 2015 / accepted on 10 March 2016 / published on 08 September 2016

Since the first documented autochthonous transmission of chikungunya virus in the Caribbean island of Saint Martin in 2013, the infection has been reported within the Caribbean region as well as North, Central and South America. The risk of autochthonous transmission of chikungunya virus becoming established in Spain may be elevated due to the large numbers of travellers returning to Spain from countries affected by the 2013 epidemic in the Caribbean and South America, as well as the existence of the Aedes albopictus vector in certain parts of Spain. We retrospectively analysed the laboratory diagnostic database of the National Centre for Microbiology, Institute of Health Carlos III (CNM-ISCIII) from 2008 to 2014. During the study period, 264 confirmed cases, of 1,371 suspected cases, were diagnosed at the CNM-ISCIII. In 2014 alone, there were 234 confirmed cases. The highest number of confirmed cases were reported from the Dominican Republic $(n=136)$, Venezuela $(n=30)$ and Haiti $(n=11)$. Six cases were viraemic in areas of Spain where the vector is present. This report highlights the need for integrated active case and vector surveillance in Spain and other parts of Europe where chikungunya virus may be introduced by returning travellers.

\section{Introduction}

Since the first outbreak in Tanzania in 1952, chikungunya has been endemic in some parts of Africa, south-east Asia and in the Indian subcontinent [1]. In 2013, however, the first documented autochthonous transmission of chikungunya virus was reported in the Caribbean island of Saint Martin [2] and since then the infection has spread quickly to other countries and territories of the Caribbean as well as to North, Central and South America [2]. As at 31 December 2014 (the final day of our study), 24,682 confirmed autochthonous cases and 1,118,763 suspected cases of chikungunya in the Americas had been reported by the Pan American Health Organization (PAHO) [3]. A large majority of these suspected autochthonous cases (n $=802,714 ; 72 \%$ ) were reported from the Caribbean, in particular from the Dominican Republic (539,099; $67 \%)$.

A chikungunya outbreak in 2005 in Réunion, a French overseas department and region, affected 266,000 people (ca $35 \%$ of the population), including 783 cases imported to metropolitan France [4]. During this outbreak, a mutation (A226V in the chikungunya virus $E$ protein) that improved the replication in Aedes albopictus was observed, giving rise to a new virus variant whose fitness in this mosquito was increased [5].

The transmission of chikungunya virus to humans occurs mainly through bite of infected Ae. aegypti or Ae. albopictus mosquitoes, which can also transmit 


\section{FIGURE 1}

Number of suspected and confirmed imported chikungunya cases by year and by month, Spain, 2008-14 (suspected $\mathrm{n}=1,371$; confirmed $\mathrm{n}=264$ )

\section{A. Imported chikungunya cases by year}

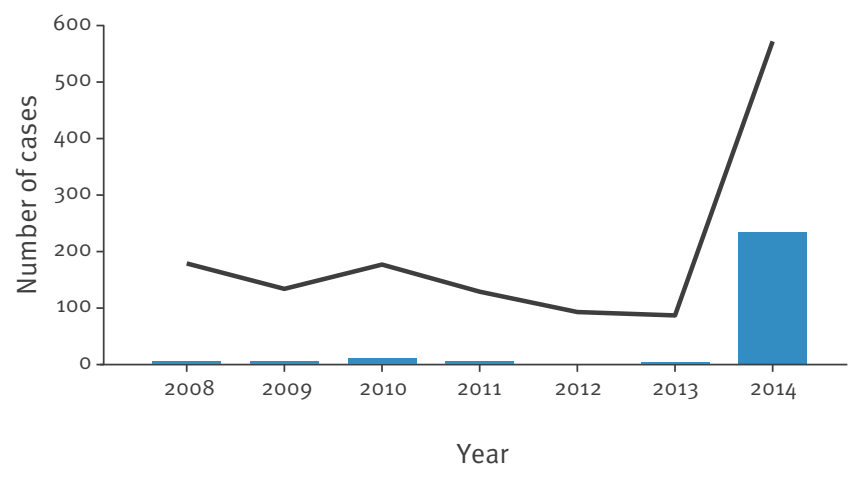

B. Imported chikungunya cases by month

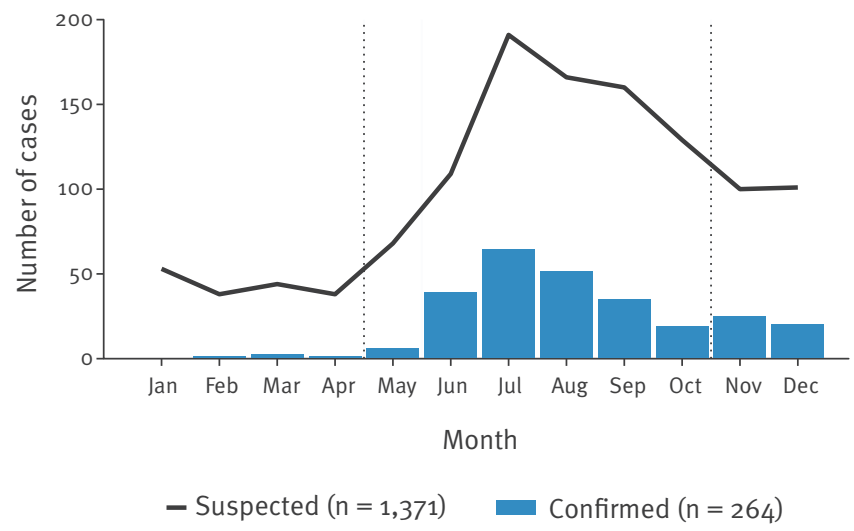

In panel $B$, the two vertical lines indicate the start and end of the active period for the chikungunya virus vector Aedes Albopictus in Spain (May to October).

dengue virus. In Europe, Ae. albopictus is established primarily around the Mediterranean basin $[6,7]$ and has been demonstrated to be competent for chikungunya virus transmission in this region [8]. This has resulted in locally acquired infections in Italy (Emilia Romagna region, 2007) as well as in France (Var and Montpellier, 2010 and 2014 respectively) [9-11].

In Spain, despite the presence of Ae. albopictus in the eastern Mediterranean regions (Catalonia, Valencia, Murcia, Balearic Islands) [12] and recently in the southern region of Andalusia [13] and in the Basque Country [14], no autochthonous transmission of chikungunya virus has been reported. However, the risk of autochthonous transmission of chikungunya establishing in Spain may be elevated due to the large numbers of travellers returning to Spain from countries affected by the 2013-14 epidemic in the Caribbean and South America [2], as well as the existence of the competent vector in certain parts of Spain. In order to further assess this risk and better understand the epidemiological and laboratory characteristics of imported chikungunya cases, we retrospectively analysed the laboratory diagnostic database of the National Centre for Microbiology, Institute of Health Carlos III (CNM-ISCIII) from 2008 to 2014 .

\section{Methods}

\section{Case definition}

The case definition used followed the guidelines provided by the Spanish Ministry of Health [15] and the European Centre for Disease Prevention and Control (ECDC) [16].

A suspected case was a patient meeting clinical criteria (acute onset of fever $\left(>38^{\circ} \mathrm{C}\right.$ ) and severe arthralgia not explained by other medical conditions) and epidemiological criteria (residing in or having visited epidemic or endemic areas).

A confirmed case was a patient meeting the laboratory criteria, irrespective of the clinical presentation (with at least one of the following: virus isolation, presence of viral RNA, presence of virus-specific IgM antibodies in a single serum sample collected in acute or convalescent stage, or fourfold rise in IgG titres in samples collected at least 15 days apart) [15]. Patients with chikungunya virus or chikungunya viral RNA detected in serum were considered viraemic.

\section{Serology and molecular analysis}

The presence of IgM or IgG antibodies against chikungunya virus was detected by indirect immunofluorescence (Euroimmun, Germany).

The presence of dengue virus IgG and IgM antibodies was detected using IgM capture ELISA and IgG indirect ELISA tests [17].

The presence of chikungunya viral RNA was detected by an in-house real-time reverse transcription-PCR (RT-PCR) and confirmed by two established PCR protocols [18].

\section{Dengue diagnostics}

Dengue viral RNA was detected using RT-PCR [19]. Dengue nonstructural protein 1 antigen (NS1) was detected by enzyme immunoassay (Platelia Dengue NS1 Ag, Biorad).

\section{Data used}

All data from samples received for diagnosis and surveillance of imported viral infections in the CNM-ISCIII between 1 January 2008 and 31 December 2014 were included in the study. Samples and data were codified with a unique ID to ensure the anonymity of patients.

We accessed the CNM-ISCIII database, in which information was typically collected on sex, age, date of onset of symptoms, date of specimen collection, travel destination and hospitalisation. We also contacted 
Geographical spread of confirmed imported chikungunya cases $(\mathrm{n}=264)$ and presence of chikungunya virus vector Aedes albopictus in autonomous regions of Spain, 2008-14

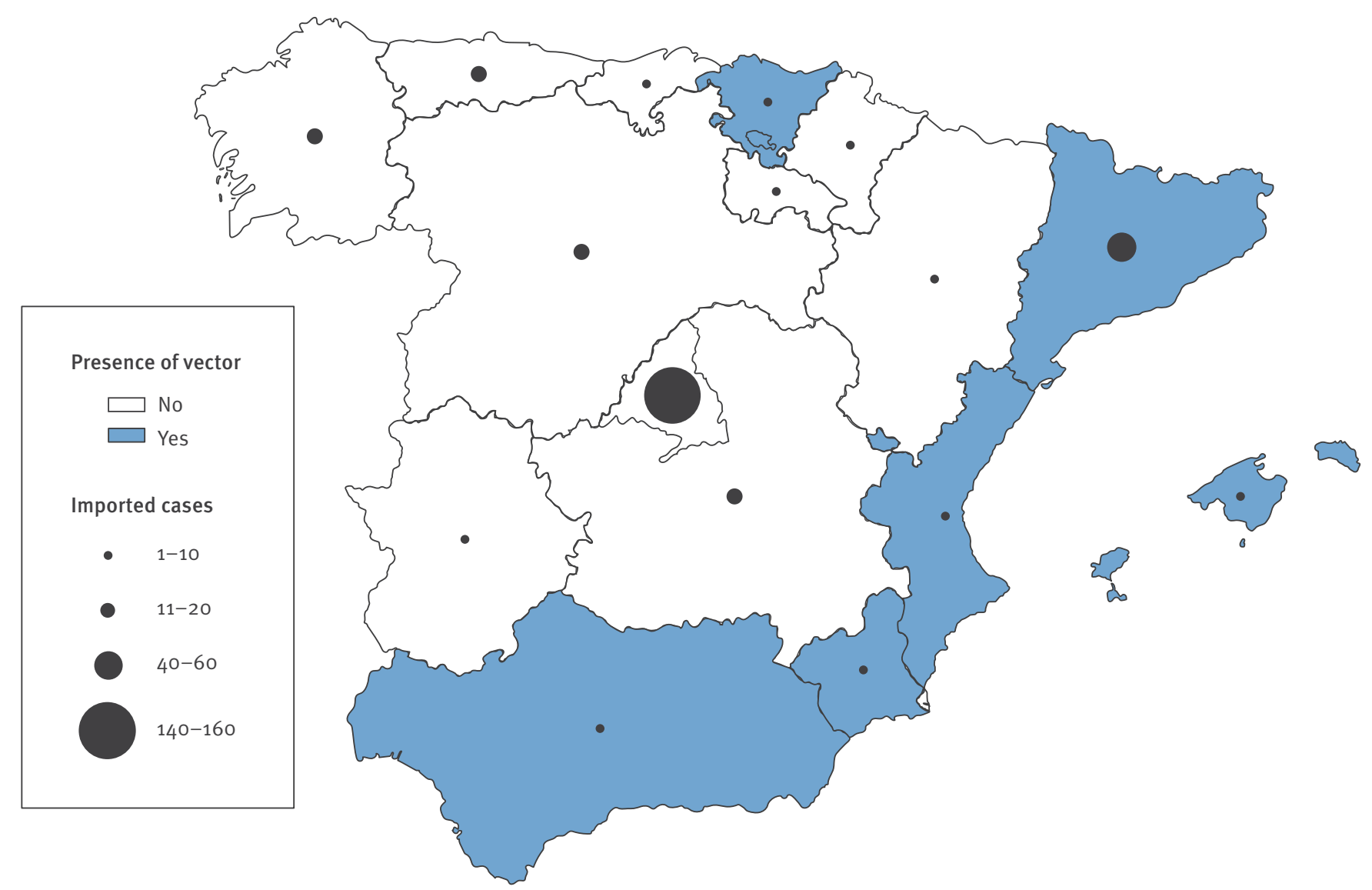

local health authorities and hospitals to retrieve information on travel destination. Samples included acute and convalescent sera. We used international travel statistics obtained from a 2014 World Tourism Organization report [20] to estimate incidence rates of chikungunya virus-infected travellers returning to Spain.

\section{Results}

Infections reported and patient characteristics During the study period (1 January 2008 to 31 December 2014), a total of 1,371 suspected chikungunya cases were identified (179 in 2008, 134 in 2009, 177 in 2010, 129 in 2011, 93 in 2012, 87 in 2013 and 572 in 2014). The most frequently reported reasons for travel were work (aid workers, missionaries, others), visiting friends and relatives and tourism. In 2008-13, the median number of suspected cases was 131 (range: 87-179). Of the 1,371 suspected cases in $2008-14,42 \%(n=572)$ were reported in 2014 alone.

A total of 264 (19\%) suspected cases were laboratory confirmed by CNM-ISCIII during the study period. Of the confirmed cases, the majority were female $(\mathrm{n}=$ $159 ; 60 \%$ ), with a median age of 43 years (range: $1-93$ ). The number of suspected and confirmed imported cases from 2008 to 2014 in Spain is shown in Figure 1A. During 2008-13, 30 imported chikungunya cases were laboratory confirmed (6 in 2008, 4 in 2009, 11 in 2010, 5 in 2011, 1 in 2012, 3 in 2013) with a median of 5 (range: 1-11) cases identified per year, while in 2014 there were 234 confirmed imported cases. The ratio of confirmed to suspected cases shifted from 1:28 in 2008-2013 to 1:3 in 2014. The distribution of imported cases by month during our study period in Spain shows that the number of confirmed and suspected cases reached its peak during July (Figure $1 \mathrm{~B}$ ).

\section{Travel history}

The travel history of the patients is detailed in Table 1. Between 2008 and 2013, the travel destination was known for 19 of the 30 confirmed cases: 17 cases had travelled to Asia (Indonesia $(n=5)$, India $(n=5)$, Myanmar $(n=2)$, Thailand $(n=1)$, Philippines, $(n=1)$, other Asian countries not specified $(n=3)$ ) and two cases had travelled to Africa (Cameroon and Equatorial Guinea). Of the 234 cases in 2014 , the travel history of 220 patients (94\%) was known: 154 cases (70\%) reported having visited the Caribbean during the incubation period [16], 59 cases had visited Central and South America (Venezuela, Colombia, Mexico, Nicaragua, Peru, El Salvador, Panama), five had visited Africa (Angola, Madagascar, Equatorial Guinea, and 
TABLE 1

Number of confirmed chikungunya cases $(n=264)$ and incidence rate of chikungunya among travellers returning to Spain, by travel destination, 2008-2014

\begin{tabular}{|c|c|c|c|c|c|}
\hline \multirow{2}{*}{$\begin{array}{l}\text { Travel destinations - } \\
\text { countries and territories }\end{array}$} & \multirow{2}{*}{$\begin{array}{l}\text { Mean annual number } \\
\text { of travellers from Spain } \\
\text { during } 2008-13^{\mathrm{a}}\end{array}$} & \multicolumn{2}{|r|}{$2008-13$} & \multicolumn{2}{|r|}{2014} \\
\hline & & $\begin{array}{l}\text { Number of } \\
\text { cases }\end{array}$ & $\begin{array}{l}\text { Incidence rate per } 100,000 \\
\text { travellers arriving in Spain }\end{array}$ & $\begin{array}{l}\text { Number of } \\
\text { cases }\end{array}$ & $\begin{array}{l}\text { Incidence rate per } 100,000 \\
\text { travellers arriving in Spain }\end{array}$ \\
\hline \multicolumn{6}{|l|}{ Americas } \\
\hline Venezuela & 610,333 & 0 & 0 & 30 & 4.92 \\
\hline Haiti & 317,666 & 0 & 0 & 11 & 3.46 \\
\hline Dominican Republic & $4,421,000$ & 0 & 0 & 136 & 3.08 \\
\hline Guadeloupe & 405,000 & 0 & 0 & 2 & 0.49 \\
\hline Martinique & 487,000 & 0 & 0 & 1 & 0.21 \\
\hline Colombia & $2,200,000$ & 0 & 0 & 3 & 0.14 \\
\hline Dominica & 77,250 & 0 & 0 & 1 & 1.29 \\
\hline Puerto Rico & $3,125,750$ & 0 & 0 & 3 & 0.10 \\
\hline Nicaragua & $1,083,000$ & 0 & 0 & 1 & 0.09 \\
\hline El Salvador & $1,196,000$ & 0 & 0 & 1 & 0.08 \\
\hline Panama & $1,515,250$ & 0 & 0 & 1 & 0.07 \\
\hline Peru & $2,581,000$ & 0 & 0 & 1 & 0.04 \\
\hline $\begin{array}{l}\text { Americas (unspecified, but } \\
\text { excluded North America) }\end{array}$ & $57,849,000$ & 0 & 0 & 21 & 0.04 \\
\hline Mexico & $23,365,000$ & 0 & 0 & 1 & 0.00 \\
\hline \multicolumn{6}{|l|}{ Africa } \\
\hline Mozambique & $1,911,000$ & 0 & 0 & 1 & 0.05 \\
\hline Madagascar & 218,250 & 0 & 0 & 1 & 0.46 \\
\hline Angola & 478,000 & 0 & 0 & 2 & 0.42 \\
\hline Cameroon & 664,666 & 1 & 0.15 & 0 & 0 \\
\hline Equatorial Guineab & No data & 1 & NC & 1 & $\mathrm{NC}$ \\
\hline \multicolumn{6}{|l|}{ Asia } \\
\hline India & $6,377,750$ & 5 & 0.07 & 1 & 0.02 \\
\hline Asia (unspecified) & $235,587,000$ & 3 & 0.00 & 1 & 0 \\
\hline Indonesia & $7,874,750$ & 5 & 0.06 & 0 & 0 \\
\hline Myanmar & 54,875 & 2 & 0.36 & 0 & 0 \\
\hline Thailand & $21,016,750$ & 1 & 0.00 & 0 & 0 \\
\hline Philippines & $4,097,750$ & 1 & 0.02 & 0 & 0 \\
\hline \multicolumn{6}{|c|}{ No travel destination specified } \\
\hline Cases with missing data & NA & 11 & NA & 14 & NA \\
\hline Total number of cases & NA & 30 & NA & 234 & NA \\
\hline
\end{tabular}

NA: not applicable; NC: not calculated, as no denominator data.

a Source: [20] for data from 2008 to 2012 and [45] for data from 2009 to 2013. At the time of analysis, traveller data were not available for 2014.

${ }^{\mathrm{b}}$ Traveller data were not available for Equatorial Guinea for 2008-13.

Mozambique) and two had visited Asia (India, unspecified). No autochthonous infections acquired in Spain were identified or reported by the health authorities.

The incidence rates of chikungunya in travellers worldwide returning to Spain are shown in Table 1 . The highest incidence rate in 2014 was seen in travellers returning from Venezuela, with 4.92 cases per 100,000 travellers, followed by those who had travelled to Haiti $(3.46 / 100,000)$ and the Dominican Republic (3.08/100,000). In contrast, during 2008-13, the highest incidence rate was in travellers returning from Myanmar, with 0.36 cases per 100,000 travellers.
Information about reason for travel was available for a limited number of suspected cases in $2014(n=66)$. Among those 66 suspected cases, the most frequently reported reasons for travel were visiting friends and relatives $(n=27)$, tourism $(n=25)$ and work $(n=14$; aid workers, missionaries, others).

\section{Region of notification and presence of vector} Overall, 120 hospitals in all Spanish regions referred samples to the CNM-ISCIII during the study period. Of the 264 cases confirmed between 2008 and 2014, Madrid and Catalonia had the largest number of notifications (150 (57\%) and 44 (17\%), respectively). A total 
Indirect immunofluorescence results and interval between the dates the first and second samples were taken, for convalescent paired samples from 37 confirmed cases, Spain, 2008-14

\begin{tabular}{|c|c|c|c|}
\hline \multicolumn{2}{|c|}{ Indirect immunofluorescence results } & \multirow{2}{*}{ Number of samples } & \multirow{2}{*}{$\begin{array}{l}\text { Mean time in days (range) between the dates the first and } \\
\text { second samples were taken, post symptom onset }\end{array}$} \\
\hline First sample & Second sample & & \\
\hline \multicolumn{4}{|l|}{$\lg M$} \\
\hline Pos & Pos & 17 & $43(7-79)$ \\
\hline Neg & Pos & 4 & $22.5(16-29)$ \\
\hline Neg & Neg & 4 & $117(53-181$ \\
\hline \multicolumn{4}{|l|}{$\operatorname{IgG}$} \\
\hline Pos & Pos & 17 & $108(6-210)$ \\
\hline Neg & Pos & 15 & $38(16-60)$ \\
\hline Pos & Neg & 1 & $58^{\mathrm{b}}(\mathrm{NA})$ \\
\hline
\end{tabular}

NA: not applicable; Neg: negative; Pos: positive.

a Unless otherwise specified.

b The second sample was taken 58 days after symptom onset. The date the first sample was taken was not available.

of 66 of the cases (25\%) were reported in regions where Ae. albopictus is present (Catalonia, Autonomous Community of Valencia, Basque Country, Murcia, Balearic Islands, and since 2013 southern Andalusia) (Figure 2). Of these 66 cases, six were viraemic (PCR positive) when presenting to clinicians in Spain.

In 2014, during the active period of Ae. albopictus in Spain (May-October), we confirmed a total of 33 imported cases in regions with vector presence, three of whom were viraemic when presenting to clinicians in Spain.

\section{Serological diagnostics}

Of the 33 confirmed imported cases in regions in which Ae. albopictus was present, 30 had anti-chikungunya virus IgM antibodies, suggesting recent infection.

Serology was performed on 1,147 of the 1,371 (84\%) suspected imported cases. Of the 1,147 tested, 235 (20\%) were positive for IgM. Of the 235 IgM-positive samples, 11 (5\%) also tested positive by the molecular methods described.

From 36 IgM-positive imported cases with known date of symptoms onset, samples were collected within o to 37 days after onset (median: 7 days).

Paired serum samples were available for 37 confirmed cases, where the time elapsed between the first and second samples ranged from 2 to 210 days. The results of the IgM and IgG assays are shown in Table 2. The time taken for an initially positive IgM test to become negative ranged from 93 to 181 days in our study. Among cases for whom the first sample was IgG positive, some remained IgG positive for up to 210 days, when the second sample was taken. Of 37 paired serum samples, 15 demonstrated seroconversion within 14 to 60 days.

\section{Molecular diagnostics}

Molecular diagnosis was carried out for samples from $481(35 \%)$ of the 1,371 suspected cases: viral genome was detected by RT-PCR in 39 (8\%) of the 481 tested. Of the 39 patients with a chikungunya virus-positive PCR, 11 had a known date of symptom. The samples were collected $0-3$ days after symptom onset except for one, which was collected after six days.

Of the 235 patients whose infection was confirmed by IgM, 86 were negative by PCR. For these 86 patients, the median time from onset of symptoms to sample collection was four days (range: 0-35).

\section{Concurrent infection}

Of the 1,371 suspected chikungunya cases reported during the study period, 817 were also tested for the presence of anti-dengue virus IgG and IgM antibodies, dengue RNA and/or dengue nonstructural protein 1 antigen (NS1). In $2014,41 \%(234 / 572)$ of the suspected chikungunya cases were tested for dengue virus infection while in the rest of the study period (2008-13), $73 \%(583 / 799)$ of the suspected chikungunya cases were tested for dengue virus infection. Dengue RNA, NS1 and/or anti-dengue virus IgM antibodies were found in 116 of the 1,371 suspected chikungunya cases. During 2008-13, a total of 87 imported dengue cases were laboratory confirmed (9 in 2008, 13 in 2009, 28 in 2010, 9 in 2011, 12 in 2012, 16 in 2013); in 2014, there were 29 confirmed imported dengue cases. The distribution of dengue imported cases by month in 2014 showed that the number of confirmed cases reached its peak during August (data not shown). A total of 13/29 confirmed dengue cases in August 2014 reported having visited the Americas.

Of the 116 dengue cases, five were also confirmed as positive for chikungunya virus, one in 2010 and four in 2014. Of these five, three had anti-dengue virus and 


\begin{tabular}{|c|c|c|c|c|c|c|}
\hline \multirow{2}{*}{ Case } & \multirow{2}{*}{ Confirmed dengue } & \multicolumn{3}{|c|}{ Confirmed chikungunya } & \multirow{2}{*}{ Travel destination } & \multirow{2}{*}{ Year } \\
\hline & & $\lg M$ & IgMplus PCR & PCR & & \\
\hline 1 & \multirow{4}{*}{ IgM positive } & Pos & Neg & Neg & Venezuela & 2014 \\
\hline 2 & & Pos & $\mathrm{Neg}$ & $\mathrm{Neg}$ & Philippines & 2010 \\
\hline 3 & & Pos & Neg & Neg & Dominican Republic & 2014 \\
\hline 4 & & Neg & Neg & Pos & Dominican Republic & 2014 \\
\hline 5 & IgM and PCR positive & Neg & Neg & Pos & Venezuela & 2014 \\
\hline
\end{tabular}

Neg: negative; Pos: positive.

anti-chikungunya virus IgM, one had anti-dengue virus IgM and chikungunya viral RNA, and one had dengue viral RNA and chikungunya viral RNA. The coinfected patients in 2014 had returned from Venezuela $(n=2)$ and the Dominican Republic $(n=2)$. The patient coinfected in 2010 had returned from the Philippines (Table 3).

\section{Discussion}

We have described a 7.8 fold increase in the number of imported chikungunya virus infections from 2008-13 (30 cases) to 2014 (234 cases) in Spain, with the number in 2014 being the highest recorded in the country. Every year since 2006, imported chikungunya cases have been identified among travellers returning to Spain. During 2006 to 2007,29 laboratory-confirmed imported cases were diagnosed among a cohort of 308 travellers with symptoms compatible with acute or recent chikungunya virus infection on their return to Spain [21]. The majority of these cases $(n=20)$ had visited India or the Indian Ocean Islands. Similarly, during 2008 to 2013, most imported cases (17/19) arrived from Asia. As a result of an ongoing outbreak in the Americas, with more than 780,000 suspected cases by 31 October 2014 [22], however, the majority of cases imported to Spain in 2014 were from the Caribbean and northern parts of South America [23], demonstrating the potential of this large chikungunya outbreak to affect Spain.

The Caribbean is a popular travel destination for Spanish travellers during the spring and summer months. It is also a destination for migrants living in Spain, who travel back home to visit friends and relatives, as shown by the large proportion of chikungunya cases in our study who had visited friends and relatives (27/66). Spain has a dynamic population of Latin American and Caribbean immigrants with permanent residency in Spain who frequently travel to their country of origin. Immigrants from the Caribbean, especially the Dominican Republic, have represented the one of the largest proportion of immigrants in Spain in recent decades and a continued growth of Dominican immigration is predicted for the future [24]. This correlates with the high number of confirmed chikungunya cases from the Dominican Republic (136/264) seen in our study. Furthermore, migrants visiting friends and relatives are less likely than tourists to seek travel health advice, and therefore to take preventive measures during their stay, representing an important gateway for the entry of chikungunya virus in Europe [25]. This challenge requires appropriate countermeasures such as targeted guidance to these groups of travellers at risk and early screening.

During 2015, however, the virus spread from the Caribbean to South and Central America, and more countries have become affected. The virus spread in Colombia, Venezuela, Brazil and other South American countries during the summer of 2015. In Brazil, where in 2014 a total of 3,657 cases distributed in eight municipalities were reported, in 2015 the number of cases increased more than fivefold, to 20,661 cases in 84 municipalities, mainly in north-east and south-west states [26].

Appropriate surveillance and investigation of imported chikungunya cases could also aid in understanding better the epidemiological and virological dynamics of the outbreak in the Caribbean and Latin American countries. Returning travellers can serve as indirect sentinels to monitor the geographical spread of the outbreak in the Americas. For example, in our study $52 \%$ of imported cases came from the Dominican Republic, in line with PAHO's report in October 2014 that showed $62 \%$ of cases in the Americas stem from this country [22]. Similarly, in late $2014,13 \%$ of chikungunya virus-infected travellers were returning from Venezuela, around the time the country was facing a large re-emergence of vector-borne diseases [27]. If we look in 2015 for chikungunya cases in Spain imported from Venezuela, the percentage would probably be larger due to the large epidemic there.

Sharing of data gained through analysis of returning travellers could support countries where no or scarce data on chikungunya have been reported. In our study, for example, we saw an imported case from Mozambique, a country that only recently demonstrated circulation of chikungunya virus [28]. We also saw cases in travellers returning from Colombia, El Salvador and Nicaragua, which have reported local 
transmission, and from Panama, which had reported imported cases in 2014 [3,29]. While this can serve as an indication, using travel information alone is not sufficient to definitively determine the country source of infection as travel is seasonal to most destinations and the epidemic may have been introduced before infected travellers returned.

Although the chikungunya outbreak in the Caribbean has led to an increase in the number of cases in Spain, enhanced surveillance may have also contributed to the rise. Chikungunya was classified a notifiable disease in 2013 by the Consejo Interterritorial del Sistema Nacional de Salud and became law in 2015, after our study period $[30,31]$. This may have led to greater awareness among patients and physicians, resulting in better ascertainment of suspected cases. Before the outbreak in the Caribbean, 1 in 28 suspected chikungunya cases were confirmed positive in the ISCIII whereas in 2014, the ratio was 1 in 3 (confirmed vs suspected cases). In 2008-13, of the 799 cases notified only 30 were confirmed, whereas in 2014, 234 of 572 notified cases were confirmed. Similarly, in southeastern France, an increase in the number of suspected cases was noted in 2010 due to enhanced surveillance for chikungunya implemented after autochthonous chikungunya transmission was reported [10].

Although autochthonous transmission of chikungunya has been documented in south-eastern France in 2010 and $2014[8,10]$ as well as in Italy in 2007 [9], Spain has not reported local transmission of chikungunya virus, despite the presence of $A e$. albopictus mosquitoes in the country [32]. Chikungunya virus strains with the $A 226 \mathrm{~V}$ viral mutation have not yet been described in America, as the circulating genotype is the Asian one and not the East/Central/South African (ECSA) genotype, in which the mutation arose [5]. This mutation should be considered in risk assessments of local transmission in Spain. Our data show that most travellers returned to Spain during the warm months of June to September, coinciding with the period of activity for Ae. albopictus (May-October). In 2014, the highest number of confirmed imported cases of chikungunya were in areas in which the vector was present $(n=66$; Catalonia, Autonomous Community of Valencia, Murcia, Basque Country, Balearic Islands and Andalusia). Importantly, six of these 66 confirmed cases were positive by PCR. Such viraemic travellers are potential disseminators of the virus through bites of vectors, or by donating blood [33]. The ability of infected vectors to effectively overwinter until the next hot season further adds to the importance of imported chikungunya [34]. Considering that autochthonous transmission in France in 2010 occurred following importation of only two cases of chikungunya, the high number of infected travellers returning to Spain highlights the increased risk of autochthonous transmission becoming established. It is important to note that, to date, countries affected by localised outbreaks in the EU have been able to contain further spread of the disease $[10,35]$.
Serological diagnosis can be performed by detection of specific IgM antibodies in serum from four to five days after the onset of symptoms, or a fourfold rise in chikungunya- specific IgG antibody titre in a paired serum sample. Chikungunya-specific IgM can persist for months, in particular in patients with persistent arthralgia [36]. The reported sensitivity of the commercial Immunofluorescence test used for detection of chikungunya-specific IgM has been $98.3 \%$, with a sensitivity of $96.9 \%$ [37]. The specificity and sensitivity for the detection of IgG is $100.0 \%$ and $95.4 \%$, respectively [37]. In our study, we observed that IgM can be detected from a median of seven days after onset of symptoms and that IgG can be detected from 16 days after the first sample is taken. This highlights that if specimens are collected very early in the course of the illness and tested only for IgM antibodies, serological diagnostic testing may not detect cases. In convalescent samples, we observed that IgM can persist up to 79 days. This should be taken into consideration when sampling and testing for chikungunya virus in returning travellers. Further study is also merited as complete case information for this analysis was available only for a limited subset of cases.

As chikungunya virus infection has similar symptoms as dengue and both viruses can circulate in the same area, chikungunya fever has often been mistaken for dengue. Confirmed dengue imported cases among travellers seen in our study support the suspicion of dual endemic circulation of dengue and chikungunya viruses in the Caribbean. Coinfections have been reported in Saint Martin, where $2.8 \%$ of chikungunya cases were reported as dengue coinfections in December 2013 to January 2014 [38]. In 2010, south-eastern France reported the concomitant emergence of dengue and chikungunya viruses, with two autochthonous infections reported for each $[10,35]$. Here we report five coinfections, four occurring in 2014 and one in 2010. Coinfections in travellers returning to Europe from the Indian Ocean Region in 2006 have been reported [39]. In addition, imported cases of Mayaro virus infection, an American alphavirus, were described in Germany in 2013 [40], France in 2010 [41] and the Netherlands in 2008 [42]. An imported case of O'nyong nyong virus infection, an African alphavirus, was described in Germany in 2013 [43]. Differential diagnosis of alphaviruses is therefore important and physicians should familiarise themselves with their clinical presentation.

The importance of coinfection is further highlighted as Ae. albopictus is also a recognised vector with competence and capacity to transmit dengue virus. With the increasing spread of Ae. albopictus in southern Europe, the risk of the establishment of these two arboviruses in Europe has also increased [44]. Continued awareness of other emerging diseases is needed to ensure rapid detection and control. The implementation of a strategic national surveillance system adapted to the early detection of both chikungunya and dengue, 
combined with vector monitoring systems, is urgently needed.

Considering the intense international traffic between Spain and countries affected by the 2013-14 chikungunya outbreak, as well as immigration and the distribution of competent vectors, chikungunya virus is becoming a threat to Spain and neighbouring countries. This report highlights the need for integrated active case and vector surveillance in Spain and other parts of Europe where the virus may be introduced by returning travellers. We furthermore highlight our experiences with diagnosing samples from returning travellers and how they can be used to indirectly monitor the spread of the outbreak in the Americas. An outbreak of chikungunya in Spain could have a considerable impact on public health, the safety of blood donation supplies and on tourism. With the 2013-14 outbreak in the Americas, the number of chikungunya cases among travellers returning to Spain from affected areas is likely to continue to increase, especially in the summer season in Spain. Mediterranean countries should strengthen preparedness for the re-emergence and/or reintroduction of chikungunya virus and other Aedestransmitted diseases, especially in regions where $A e$. albopictus is present or could become established.

\section{Acknowledgements}

We would like to thank: Virginia Jimenez Planet (National Library of Health, ISCIII), Hospital of Navarra, Hospital Gregorio Marañon, Hospital German Trials iPujol and BR Salud Laboratory and other hospitals belonging to the national health system. In addition we thank the two anonymous reviewers.

Financial support was provided by the Fondo de Investigaciones Sanitarias (FIS) Pl10/00069 and FIS Plo8/0834 and partially covered by DengueTools project under the Seventh Framework Programme of the European Community, Grant Agreement Number: 282589.

LF was under contract by European Network of Imported Viral Disease-Collaborative Laboratory Response Network (ENIVD-CLRN) project funded by the European Centre for Disease Prevention and Control (ECDC) under the Framework Service Contract Ref. No. ECDC/2013/012.

MPSS, JG, RLV, FN, ES, NS, DP and AN belong to RICET network (FIS RD12/0018/0006) and LF, MPSS, AV and FO belong to the ViroRed network (CYTED).

\section{Conflict of interest}

None declared

\section{Authors' contributions}

MDF, MB, LF, MPSS and AT: conceived and design the study; $A P, A N, A V, L H, P M, F L, L H R, P B, T M, J d I F, M M$ and ES: performed molecular and serological diagnosis; MDF, MB, LF, MPSS, AT, FdO, NS, JG, SP, ML, RLV, FN and RFR: contributed to acquisition, analysis and interpretation of data; MDF, MB and LF: drafted the article. All authors revised it critically and approval the final version of the article.
LF and MPSS are senior authors.

\section{References}

1. Weaver SC, Forrester NL. Chikungunya: Evolutionary history and recent epidemic spread. Antiviral Res. 2015;120:32-9. DOI: 10.1016/j.antiviral.2015.04.016 PMID: 25979669

2. Van Bortel W, Dorleans F, Rosine J, Blateau A, Rousset D, Matheus S, et al. Chikungunya outbreak in the Caribbean region, December 2013 to March 2014, and the significance for Europe. Euro Surveill. 2014;19(13):20759. DOI: 10.2807/15607917.ES2014.19.13.20759 PMID: 24721539

3. Pan American Health Organization (PAHO). Cummulative Number of Reported Cases of Chikungunya Fever in the Americas, by Country or Territory 2014. Epidemiological week 52 (updated 29 December 2014). Washington DC: PAHO; 2014. Available from: http://www.paho.org/hq/index. php?option $=$ com_topics $\&$ view $=$ readall $\&$ cid $=5932 \&$ Itemid $=40$ 931\&lang=es

4. Ledrans M, Quatresous I, Renault P, Pierre V. Outbreak of chikungunya in the French Territories, 2006: lessons learned. Euro Surveill. 2007;12(36): pii=3262.

5. Schuffenecker I, Iteman I, Michault A, Murri S, Frangeul L, Vaney MC, et al. Genome microevolution of chikungunya viruses causing the Indian Ocean outbreak. PLoS Med. 2006;3(7):e263. DOI: 10.1371/journal.pmed.0030263 PMID: 16700631

6. Gasperi G, Bellini R, Malacrida AR, Crisanti A, Dottori M, Aksoy S. A new threat looming over the Mediterranean basin: emergence of viral diseases transmitted by Aedes albopictus mosquitoes. PLoS Negl Trop Dis. 2012;6(9):e1836. doi: 10.1371/ journal.pntd.0001836.

7. Enserink M. Entomology. A mosquito goes global.Science. 2008;320(5878):864-6. DOI: 10.1126/science.320.5878.864 PMID: 18487167

8. Vega-Rua A, Zouache K, Caro V, Diancourt L, Delaunay P, Grandadam M, et al. High efficiency of temperate Aedes albopictus to transmit chikungunya and dengue viruses in the Southeast of France. PLoS One. 2013;8(3):e59716. DOI: 10.1371/journal.pone.0059716 PMID: 23527259

9. Angelini P, Macini P, Finarelli AC, Pol C, Venturelli C, Bellini $R$, et al. Chikungunya epidemic outbreak in Emilia-Romagna (Italy) during summer 2007. Parassitologia. 2008;50(1-2):97-8. PMID: 18693568

10. Grandadam $M$, Caro V, Plumet $S$, Thiberge JM, Souarès $Y$, Failloux $A B$, et al. Chikungunya virus, southeastern France. Emerg Infect Dis. 2011;17(5):910-3. DOI: 10.3201/ eid1705.101873 PMID: 21529410

11. Delisle E, Rousseau C, Broche B, Leparc-Goffart I, L'Ambert G, Cochet $A$, et al. Chikungunya outbreak in Montpellier, France, September to October 2014. Euro Surveill. 2015;20(17):21108. DOI: $10.2807 / 1560-7917 . E S 2015 \cdot 20.17 .21108$ PMID: 25955774

12. Alarcón-Elbal PM, Estrella SD, Arrondo IR, Collantes F, Iniesta JA, Morales-Bueno J, et al. Updated distribution of Aedes albopictus (Diptera: Culicidae) in Spain: new findings in the mainland Spanish Levante, 2013. Mem Inst Oswaldo Cruz. 2014;109(6):782-6. DOI: 10.1590/0074-0276140214 PMID: 25317706

13. Delacour-Estrella SCF, Ruiz Arrondo I, Alarcón-Elbal PM, Delgado JA, Eritja R, Bartumeus F, et al. Primera cita de mosquito tigre, Aedes albopictus (Diptera, Culicidae), para Andalucía y primera corroboración de los datos de la aplicación Tigatrapp. [First Record of Asian Tiger Mosquito, Aedes Albopictus (Diptera, Culicidae), in Anadalusia and First Corroboration of the Data from Tigatrapp Application]. Anales De Biología 2014;36:93-6. Spanish.

14. Delacour S, Barandika JF, García-Pérez AL, Collantes F, RuizArrondo I, Alarcón-Elbal PM, et al. Detección temprana de mosquito tigre, Aedes albopictus (Skuse, 1894), en el País Vasco (España). [Early detection of tiger mosquito, Aedes albopictus (Skuse, 1894), in the Basque Country (Spain)]. Anales de Biologia, 2015;37:25-30. Spanish.

15. Spanish Ministry of Health, Social Services and Equality. Información para profesionales sanitarios: fiebre chickungunya. [Chikungunya fever: information for health professionals]. Spanish. Madrid: Spanish Ministry of Health, Social Services and Equality. [Accessed 15 Jun 2015]. Spanish. Available from: http://www.msssi.gob.es/profesionales/ saludPublica/ccayes/alertasActual/docs/Informacion Profesionales_Sanitarios_CHIKV.pdf

16. European Centre for Disease Prevention and Control (EDCD). Information for Health Practitioners. Chikungunya Virus. Stockholm: ECDC. [Accessed 2 Feb 2015]. Available 
from: http://ecdc.europa.eu/en/healthtopics/Documents/ Chikungunya_Fever_Factsheet_for_Health_Practitioners.pdf

17. Domingo C, de Ory F, Sanz JC, Reyes N, Gascón J, Wichmann 0 , et al. Molecular and serologic markers of acute dengue infection in naive and flavivirus-vaccinated travelers. Diagn Microbiol Infect Dis. 2009;65(1):42-8. DOI: 10.1016/j. diagmicrobio.2009.05.004 PMID: 19679234

18. Collao X, Negredo Al, Cano J, Tenorio A, Ory F, Benito A, et al. Different lineages of Chikungunya virus in Equatorial Guinea in 2002 and 2006. Am J Trop Med Hyg. 2010;82(3):505-7. DOI: 10.4269/ajtmh.2010.09-0435 PMID: 20207882

19. Domingo C, Niedrig M, Gascón J, Palacios G, Reyes N, Malo MJ, et al. Molecular surveillance of circulating dengue genotypes through European travelers. J Travel Med. 2011;18(3):183-90. DOI: 10.1111/j.1708-8305.2011.00501.x PMID: 21539658

20. World Tourism Organization (UNWTO). UNWTO Tourism Highlights. 2014 Edition. Madrid: UNWTO; 2014. Available from: http://www.e-unwto.org/doi/ book/10.18111/9789284416226

21. Sánchez-Seco MP, Negredo Al, Puente S, Pinazo MA, Shuffenecker I, Tenorio A, et al. [Microbiological diagnosis of chikungunya virus in Spain (2006-2007): case detection in travelers]. Enferm Infecc Microbiol Clin. 2009;27(8):457-61. Spanish. DOI: 10.1016/j.eimc.2008.07.011 PMID: 19524328

22. Pan American Health Organization (PAHO). Cummulative Number of Reported Cases of Chikungunya Fever in the Americas, by Country or Territory 2014. Epidemiological week 44 (updated 31 October 2014). Washington DC: PAHO; 2014. Available from: http://www.paho.org/hq/index. php?option $=$ com_topics \&view $=$ readall $\&$ cid $=5932 \&$ Itemid $=40$ 931\&lang=es

23. Requena-Méndez A, Garcia C, Aldasoro E, Vicente JA, Martínez MJ, Pérez-Molina JA, et al. Cases of chikungunya virus infection in travellers returning to Spain from Haiti or Dominican Republic, April-June 2014. Euro Surveill. 2014;19(28):20853. DOI: 10.2807/1560-7917. ES2014.19.28.20853 PMID: 25060571

24. Instituto Nacional de Estadistica (INE). Avance del Padrón municipal a 1 de enero de 2010. Datos provisionales. [The progress of Municipal Register at 1 January 2010. Provisional data]. Madrid: INE. Press release. Available from: http://ine.es/ prensa/np595.pdf

25. Warne B, Weld LH, Cramer JP, Field VK, Grobusch MP, Caumes $E$, et al. , EuroTravNet Network. Travel-related infection in European travelers, EuroTravNet 2011.J Travel Med. 2014;21(4):248-54. DOI: 10.1111/jtm.12120 PMID: 24750378

26. Ministerio da Saude Brasil. Monitoramento dos casos de dengue, febre de chikungunya e febre pelo vírus Zika até a Semana Epidemiológica 52, 2015. [Data monitoring for dengue, chikungunya and zika cases, epidemiological week 52 , 2015]. Boletim Epidemiológico. 2016;47(3):1-10. Portuguese. Available from: http://portalsaude.saude.gov.br/images/ pdf/2016/janeiro/15/svs2016-beo03-dengue-se52.pdf

27. Burki T. Re-emergence of neglected tropical diseases in Venezuela.Lancet Infect Dis. 2015;15(6):641-2. DOI: 10.1016/ S1473-3099(15)00011-0 PMID: 26008842

28. Gudo ES, Vene S, Manhica I, Deus ND, Mandlaze A, Muianga $A$, et al. First evidence of circulation of chikungunya virus in Mozambique. 16th International Congress on Infectious Diseases. 16th International Congress on Infectious Diseases. Pre-Congress Symposium: Emerging African Investigators Symposium. Cape Town, South Africa. 2 Apr 2014.

29. Alfaro-Toloza P, Clouet-Huerta DE, Rodríguez-Morales A). Chikungunya, the emerging migratory rheumatism. Lancet Infect Dis. 2015;15(5):510-2. DOI: 10.1016/S14733099(15)70160-X PMID: 25932584

30. Centro Nacional de Epidemiología, Instituto de Salud Carlos III, Red Nacional de Vigilancia Epidemiológica. Protocolos de enfermedades de declaración obligatoria. [Protocols for notifiable diseases]. Madrid: Centro Nacional de Epidemiología, Instituto de Salud Carlos III, Red Nacional de Vigilancia Epidemiológica; 2013. Spanish. Available from: http://www.isciii.es/ISCIII/es/contenidos/fd-servicioscientifico-tecnicos/fd-vigilancias-alertas/PROTOCOLOS RENAVE.pdf

31. I. Disposiciones generals. Ministerio de Sanidad, Servicios Sociales e Igualdad. [I. General Provisions. Ministry of Health, Social Services and Equality]. Boletin Oficial del Estado. 2015;65:24012-5. 17 Mar 2015. BOE-A-2015-2837. Spanish. Available from: http://www.boe.es/boe/dias/2015/03/17/pdfs/ BOE-A-2015-2837.pdf

32. Giménez N, Barahona M, Casasa A, Domingo A, Gavagnach M, Martí C. [Introduction of Aedes albopictus in Spain: a new challenge for public health]. Gac Sanit. 2007;21(1):25-8. Spanish.PMID: 17306183
33. European Centre for Disease Prevention and Control (ECDC). Rapid Risk assessment. Chikungunya outbreak in Caribbean region. 25 june 2014. Stockholm: ECDC; 2014. Available from: http://www.ecdc.europa.eu/en/publications/Publications/ chikungunya-caribbean-june-2014-risk-assessment.pdf

34. Romi R, Severini F, Toma L. Cold acclimation and overwintering of female Aedes albopictus in Roma.J Am Mosq Control Assoc. 2006;22(1):149-51. DOI: 10.2987/8756-971X(2006)22[149:CAAO OF]2.0.CO;2 PMID: 16646341

35. La Ruche G, Souarès Y, Armengaud A, Peloux-Petiot F, Delaunay $P$, Desprès $P$, et al. First two autochthonous dengue virus infections in metropolitan France, September 2010. Euro Surveill. 2010;15(39):19676.PMID: 20929659

36. Borgherini G, Poubeau P, Jossaume A, Gouix A, Cotte L, Michault A, et al. Persistent arthralgia associated with chikungunya virus: a study of 88 adult patients on reunion island. Clin Infect Dis. 2008;47(4):469-75. DOI: 10.1086/590003 PMID: 18611153

37. Litzba N, Schuffenecker I, Zeller H, Drosten C, Emmerich $\mathrm{P}$, Charrel R, et al. Evaluation of the first commercial chikungunya virus indirect immunofluorescence test. J Virol Methods. 2008;149(1):175-9. DOI: 10.1016/j. jviromet.2008.01.004 PMID: 18294706

38. Omarjee R, Prat C, Flusin O, Boucau S, Tenebray B, Merle O, et al. Importance of case definition to monitor ongoing outbreak of chikungunya virus on a background of actively circulating dengue virus, St Martin, December 2013 to January 2014. Euro Surveill. 2014;19(13):20753. DOI: 10.2807/1560-7917. ES2014.19.13.20753 PMID: 24721537

39. Panning M, Grywna K, van Esbroeck M, Emmerich P, Drosten $C$. Chikungunya fever in travelers returning to Europe from the Indian Ocean region, 2006.Emerg Infect Dis. 2008;14(3):41622. DOI: 10.3201/eid1403.070906 PMID: 18325256

40. Friedrich-Jänicke B, Emmerich P, Tappe D, Günther S, Cadar $D$, Schmidt-Chanasit J. Genome analysis of Mayaro virus imported to Germany from French Guiana.Emerg Infect Dis. 2014;20(7):1255-7. DOI: 10.3201/eid2007.140043 PMID: 24960052

41. Receveur MC, Grandadam M, Pistone T, Malvy D. Infection with Mayaro virus in a French traveller returning from the Amazon region, Brazil, January, 2010.Euro Surveill. 2010;15(18):19563. PMID: 20460093

42. Hassing RJ, Leparc-Goffart I, Blank SN, Thevarayan S, Tolou $H$, van Doornum $G$, et al. Imported Mayaro virus infection in the Netherlands. J Infect. 2010;61(4):343-5. DOI: 10.1016/j. jinf.2010.06.009 PMID: 20600300

43. Tappe D, Kapaun A, Emmerich P, Campos RM, Cadar D, Günther $S$, et al. O'nyong-nyong virus infection imported to Europe from Kenya by a traveler. Emerg Infect Dis. 2014;20(10):1766-7. DOI: 10.3201/eid2010.140823 PMID: 25271361

44. Gould EA, Gallian P, De Lamballerie X, Charrel RN. First cases of autochthonous dengue fever and chikungunya fever in France: from bad dream to reality!Clin Microbiol Infect. 2010;16(12):1702-4. DOI: 10.1111/j.1469-0691.2010.03386.x PMID: 21040155

45. World Tourism Organization (UNWTO). Compendium of Tourism Statistics, 2015 Edition. Madrid: UNWTO; 2015. Available from: http://statistics.unwto.org/news/2015-02-11/ compendium-tourism-statistics-2015-edition

\section{License and copyright}

This is an open-access article distributed under the terms of the Creative Commons Attribution (CC BY 4.0) Licence. You may share and adapt the material, but must give appropriate credit to the source, provide a link to the licence, and indicate if changes were made.

This article is copyright of the authors, 2016. 